\title{
Impact of Water Chemistry on Lead Carbonate Dissolution in Drinking Water Distribution Systems
}

\author{
Maryam Mohammadzadeh ${ }^{1}$, Onita D. Basu ${ }^{1}$, Jose E. Herrera ${ }^{2}$ \\ ${ }^{1}$ Department of Civil and Environmental Engineering, Carleton University, Ottawa, Canada \\ ${ }^{2}$ Department of Civil and Environmental Engineering, Western University, London, Canada \\ Email: ${ }^{*}$ Onita.basu@carleton.ca
}

Received 1 December 2015; accepted 23 March 2015; published 25 March 2015

Copyright (C) 2015 by authors and Scientific Research Publishing Inc.

This work is licensed under the Creative Commons Attribution International License (CC BY). http://creativecommons.org/licenses/by/4.0/

c) (i) Open Access

\begin{abstract}
Elemental lead is a known toxic metal that can pose threats to human health and can be found in a variety of sources including drinking water at very low level concentrations (i.e. $\mu \mathrm{g} / \mathrm{L}$ range). Destabilization of the corrosion scale at the inner layer of pipeline is the major source of lead in drinking water. Chemical properties of the water passing through the distribution system such as pH, alkalinity, chlorine content, oxidation reduction potential (ORP) and natural organic matters will affect the formation and/or destabilization of the corrosion scale. This research examines the impact of $\mathrm{pH}$ values $\left(7.0\right.$ - 9.5), temperatures $\left(5^{\circ} \mathrm{C}\right.$ vs $\left.20^{\circ} \mathrm{C}\right)$ and alkalinity levels (moderate vs low), in the presence of chlorine, on dissolution of hydrocerussite and cerussite in drinking water by various sets of batch dissolution experiments. The results showed dissolution of cerussite and hydrocerussite was not impacted significantly by $\mathrm{pH}$ ranging 7.0 - 9.5. In addition, and somewhat surprisingly, cold temperature $\left(5^{\circ} \mathrm{C}\right)$ and moderate alkalinity showed a great influence on decreasing the solubility of lead species.
\end{abstract}

\section{Keywords}

Hydrocerussite, Cerussite, Lead Dissolution, Cold Temperature

\section{Introduction}

Elemental lead is a known toxic metal that can pose threats to human health and can be found in a variety of sources including lead paints, dust, municipal waste incineration, mining activities, gasoline additives and drink-

\footnotetext{
"Corresponding author.
} 
ing water [1]-[4]. Lead is a known carcinogen which can lead to serious health problems such as: disruption of kidney function, interfering in synthesis of haemoglobin, interruption in immune system and miscarriages [5] [6].

In particular, its impact on children's neurobehavioral and intelligence development, brain cell function and learning abilities has been shown in numerous studies [7]-[11]. Although children's average blood lead level (BLL) in many countries and areas such as United States, Mexico, Australia, Ecuador and Taiwan has generally been decreasing over the last three decades, lead poisoning in children is still of great concern [12]-[16].

According to the drinking water quality guideline published by the World Health Organization (WHO), the recommended provisional limit of lead in drinking water is $10 \mu \mathrm{g} / \mathrm{L}(\mathrm{ppb})$. This limit is adopted as the drinking water standard in many countries including Canada, Australia, China and European Union, while in United States the guideline value is $15 \mu \mathrm{g} / \mathrm{L}$ [17]-[21]. Dissolution of lead in drinking water, also known as plumbosolvency, is mainly because of lead containing materials used in water distribution systems and household plumbing, which is influenced by various water quality characteristics. Existing corrosion scales in lead pipes, solders, brass fittings and plumbing fixtures used in drinking water distribution systems are currently considered as a major problem for municipalities [9] [22] [23]. Destabilization of the corrosion scale in the distribution systems is the main source of lead in drinking water. X-ray diffraction (XRD) results of pipes collected from distribution system in City of London, Ontario, Canada by Kim and Herrera [22] have shown the main lead solid phase in the corrosion scale is hydrocerussite $\left(\mathrm{Pb}_{3}\left(\mathrm{CO}_{3}\right)_{2}(\mathrm{OH})_{2}\right.$. Additionally, in few cases cerussite $\left(\mathrm{PbCO}_{3}\right)$ was also observed. Lead oxides such as plattnerite $\left(\mathrm{PbO}_{2}\right)$ and minium $\left(\mathrm{Pb}_{3} \mathrm{O}_{4}\right)$ can also be found in the inner layers of the corrosion scale. However, these species are more stable and tend to not dissolve [22] [24]. The corrosion scale can decrease the lead level in drinking water via a passivating layer, which can also trap toxic elements and decrease their concentration in drinking water as well.

Chemical properties of the water passing through the distribution system such as $\mathrm{pH}$, alkalinity, chlorine content, oxidation reduction potential (ORP) and natural organic matters will affect the formation or destabilization of the corrosion scale. Temperature can also affect the stability of corrosion scales [1] [22] [23]. Numerous studies have shown the importance of the water $\mathrm{pH}$ in controlling the stability of the corrosion scale. For instance, at $\mathrm{pH}$ values less than 7.0, the corrosivity of water is very high and lead concentrations will increase significantly. However, pH effects can be mitigated by presence of alkalinity. In higher value of alkalinity, lead complexes formed with hydroxide and carbonate ions are insoluble and this greatly slows down the kinetics of lead dissolution [22] [23]. Free chlorine, $\mathrm{HOCl}$ and $\mathrm{OCl}^{-}$, a common disinfectant used in distribution systems, provides a high ORP that has been found to lead to the formation of insoluble solid phases such as $\mathrm{PbO}_{2}$ and preventing the dissolution of lead species [20] [25].

So far, researches have primarily focused on the effect of the $\mathrm{pH}$ at $20^{\circ} \mathrm{C}$ (i.e. [1] [24] [26]) and there is no research conducted at cold temperature $\left(5^{\circ} \mathrm{C}\right)$. Since there are countries such as Canada experiencing cold temperature about 6 months per year, it is important to investigate the influence of cold temperature on lead dissolution. Therefore, the objective of this paper is to explore the effects of different temperature conditions $\left(20^{\circ} \mathrm{C}\right.$ vs. $5^{\circ} \mathrm{C}$ ) on dissolution of hydrocerussite and cerussite in drinking water at bench scale under various $\mathrm{pH}$ and alkalinity (moderate vs. low) conditions.

\section{Materials and Methods}

Based on studies showing that hydrocerussite $\left(\mathrm{Pb}_{3}\left(\mathrm{CO}_{3}\right)_{2}(\mathrm{OH})_{2}\right)$ and cerussite $\left(\mathrm{PbCO}_{3}\right)$ are widely observed in the corrosion scale [22] [26], batch dissolution experiments were conducted using pure hydrocerussite and cerussite solids to investigate the lead solubility under different $\mathrm{pH}$ values (7.0, 8.0 and 9.5) and temperature conditions $\left(20^{\circ} \mathrm{C}\right.$ and $\left.5^{\circ} \mathrm{C}\right)$. An environmental chamber was utilized for temperature control of the $5^{\circ} \mathrm{C}$ experiments. Trace element grade chemicals and plastic wares were utilized to avoid cross contamination. Batch dissolution experiments were started by adding $0.3 \mathrm{~g}$ of either hydrocerussite (Aldrich, 99.44\%) or cerussite (Aldrich, 99.99\%) to $300 \mathrm{ml}$ sealed polypropylene bottles then filled with solutions. Solutions contained $0.1 \mathrm{M} \mathrm{NaNO}_{3}$ (Aldrich, 99.995\%, trace element basis), $20 \mathrm{mg} \mathrm{C} / \mathrm{L}$ of dissolved inorganic carbon $\left(\mathrm{CaCO}_{3}\right.$ or $\mathrm{NaHCO}_{3}\left(\mathrm{Sig}_{-}\right.$ ma-Aldrich, ACS reagent) and $1 \mathrm{mg} / \mathrm{L} \mathrm{Cl}_{2}$ (NaHClO, Aldrich, reagent grade). Solution $\mathrm{pH}$ values were adjusted by adding either $2 \% \mathrm{HNO}_{3}$ (Fischer Scientific, trace metal analysis) or $1 \mathrm{M} \mathrm{NaOH}$ (Sigma-Aldrich, ACS reagent). The solutions were unbuffered. The bottles filled with solutions with no head space were set up on a shaker (VWR, DS-500E) at 170 rpm and continuously mixed throughout the experiment. A 12 ml Luer Lock sy- 
ringe (Henkle Sass Wolf) was used for sample collection. Duplicate samples were collected from each bottle and each sample was analyzed in triplicate. Collected samples were $10 \mathrm{ml}$ in volume and filtered through a $0.2 \mu \mathrm{m}$ membrane filter (VWR, polyethersulfone membrane) with the initial $2 \mathrm{ml}$ discarded and the remainder collected in a $15 \mathrm{ml}$ centrifuge vial (Diamed, polypropylene). The collected filtrate was acidified with $150 \mu \mathrm{l}$ of $2 \% \mathrm{HNO}_{3}$. Vials were stored in at $4^{\circ} \mathrm{C}$ until analyzed with inductively coupled plasma mass spectrometry (ICP-MS) (Agilent Technologies 7700x) or inductively coupled plasma optical emission spectrometry (ICP-OES) (VarianVista-PRO CCD Simultaneous ICP-OES) for lead concentration. For ICP-MS analysis, samples were diluted 5 times with $2 \% \mathrm{HNO}_{3}$ prior to analysis and for ICP-OES samples were nitrified with $1 \mathrm{ml} 70 \% \mathrm{HNO}_{3}$ without any dilution. The remainder of the batch solutions was used for measuring free chlorine and $\mathrm{pH}$. Free chlorine and $\mathrm{pH}$ were measured respectively with HACH spectrometer (DR 2800) by USEPA DPD method 8021 and HACH pH meter (HQ 40d).

\section{Experiments}

Temperature and $\mathrm{pH}$ : Experiments were conducted at $20^{\circ} \mathrm{C}$ and $5^{\circ} \mathrm{C}$ for cerussite and hydrocerussite over a range of $\mathrm{pH}$ values (7.0, 8.0 and 9.5) and in the presence of $140 \mathrm{mg} / \mathrm{L} \mathrm{NaHCO}$ as dissolved inorganic carbon (DIC) which provides moderate alkalinity in the solutions. Free chlorine, $\mathrm{pH}$ and dissolved lead were measured at regular time intervals starting at 15 minutes with the experiments lasting up to 45 days.

Alkalinity: To investigate the possible interference of alkalinity level on lead solubility, a set of experiments was carried out for cerussite and hydrocerussite at $\mathrm{pH} 8.0$ with two different DIC sources $\left(\mathrm{NaHCO}_{3}\right.$ versus $\mathrm{CaCO}_{3}$ ) at $20^{\circ} \mathrm{C}$ versus $5^{\circ} \mathrm{C} .140 \mathrm{mg} / \mathrm{L}$ of $\mathrm{NaHCO}_{3}$ was added to the solutions that was equal to $20 \mathrm{mg} \mathrm{C} / \mathrm{L}$ and provided moderate alkalinity in the solutions. For low alkalinity solutions, $75 \mathrm{mg} / \mathrm{L}$ of $\mathrm{CaCO}_{3}$ was added to the solutions to control alkalinity of solutions in low level because solubility of $\mathrm{CaCO}_{3}$ is low and the excess amount of $\mathrm{CaCO}_{3}$ will precipitate.

Free chlorine, $\mathrm{pH}$ and dissolved lead were measured at regular time intervals up to 45 days. Table 1 shows a summary of the experimental conditions examined in this research.

\section{Results and Discussion}

\subsection{Temperature and $\mathrm{pH}$ Experiments}

The impact of temperature and $\mathrm{pH}$ were studied on the dissolution of cerussite and hydrocerussite which were widely seen in corrosion scale. Batch dissolution experiments were conducted for $\mathrm{pH} 7.0,8.0$ and 9.5 at $20^{\circ} \mathrm{C}$ and $5^{\circ} \mathrm{C}$. The average values for the respective dissolved lead species are presented in Figure 1.

Comparing Figure 1 (a) $\left(20^{\circ} \mathrm{C}\right)$ and Figure $1(\mathrm{~b})\left(5^{\circ} \mathrm{C}\right)$, it can be observed that the dissolution of lead species is mainly dependent on the temperature while $\mathrm{pH}$ ranging from 7.0 to 9.5 does not show a significant role. Kim et al. [1] observed similar results for $\mathrm{pH}$ ranging from 8.0 to 10.0. Comparing results in different temperatures for both cerussite and hydrocerussite, lead solubility was about $70-80 \mu \mathrm{g} / \mathrm{L}$ average at $20^{\circ} \mathrm{C}$ versus $50 \mu \mathrm{g} / \mathrm{L}$ average at $5^{\circ} \mathrm{C}$. Xie and Giammar [27] conducted a research at $20^{\circ} \mathrm{C}$ on dissolution of plattnerite in different $\mathrm{pH}$ values ranged from 7.5 to 10 . The lead concentration showed a significant drop after the initial period and then fluctuated around $50 \mu \mathrm{g} / \mathrm{L}$. That proves the fact hydrocerussite and cerussite are more soluble than plattnerite.

Table 1. Lead dissolution experiments with different temperatures, $\mathrm{pH}$ values and alkalinity levels.

\begin{tabular}{|c|c|c|c|}
\hline Lead Compound & Temperature & $\mathrm{pH}$ & Alkalinity level \\
\hline \multicolumn{4}{|c|}{ Temperature and pH Experiments } \\
\hline Hydrocerussite & $20^{\circ} \mathrm{C}$ and $5^{\circ} \mathrm{C}$ & $7.0,8.0,9.5$ & Moderate \\
\hline \multirow[t]{2}{*}{ Cerussite } & $20^{\circ} \mathrm{C}$ and $5^{\circ} \mathrm{C}$ & $7.0,8.0,9.5$ & Moderate \\
\hline & kalinity Experim & & \\
\hline Hydrocerussite & $20^{\circ} \mathrm{C}$ and $5^{\circ} \mathrm{C}$ & 8.0 & Moderate or Low \\
\hline Cerussite & $20^{\circ} \mathrm{C}$ and $5^{\circ} \mathrm{C}$ & 8.0 & Moderate or Low \\
\hline
\end{tabular}



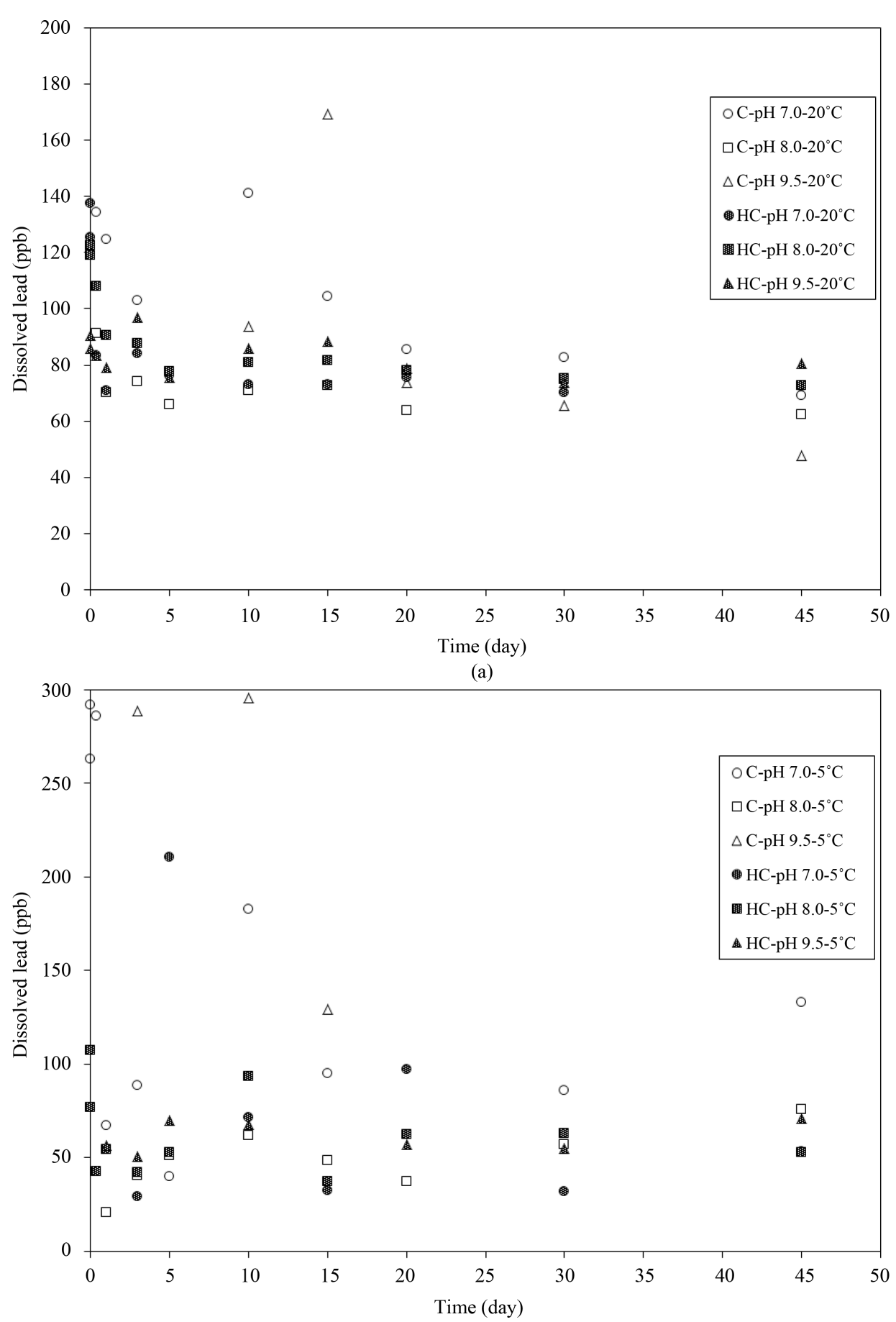

(b)

Figure 1. Dissolved lead concentration for cerussite and hydrocerussite at (a) $20^{\circ} \mathrm{C}$ and (b) $5^{\circ} \mathrm{C}$ at various $\mathrm{pH}$ values (C represents cerussite and $\mathrm{HC}$ represents hydrocerussite).

The dissolved lead concentrations for both cerussite and hydrocerussite at all pH values at $20^{\circ} \mathrm{C}$ (Figure 1 (a)) decreased within the first $24 \mathrm{~h}$ and then remained relatively constant for 45 days. In contrast, for the $5^{\circ} \mathrm{C}$ experiments (Figure 1(b)) dissolved lead concentrations from both cerussite and hydrocerussite at all $\mathrm{pH}$ values fluctuated over the 45 days. Kim and Herrera [22] hypothesized the transformation of lead carbonate species. According to Reaction (1), hydrocerussite and cerussite can transform to each other. The fluctuation may be the 
result of frequent transformation or impact of temperature on kinetics of the reaction.

$$
\mathrm{Pb}_{3}\left(\mathrm{CO}_{3}\right)_{2}(\mathrm{OH})_{2}+\mathrm{H}_{2} \mathrm{CO}_{2} \rightleftharpoons 3 \mathrm{PbCO}_{3}+2 \mathrm{H}_{2} \mathrm{O}
$$

Although a large impact of $\mathrm{pH}$ has been observed on plattnerite $\left(\mathrm{PbO}_{2}\right)$ solubility [24], this study found that for cerussite and hydrocerussite the dissolution trends were similar at all $\mathrm{pH}$ values studied, which is consistent with the results obtained for the dissolution rate of hydrocerussite by Noel et al. [26]. The study by Liu et al. [28] showed the reaction of cerussite with chlorine was very slow. This means the transformation of cerussite to plattnerite was very slow, which can explain the high concentration of cerussite before 15 days shown in Figure 1(b).

At both $20^{\circ} \mathrm{C}$ and $5^{\circ} \mathrm{C}$, the solubility of cerussite decreased as $\mathrm{pH}$ increased, while the solubility of hydrocerussite had almost no difference between $\mathrm{pH} 7.0$ and $\mathrm{pH} 8.0$ but increased at $\mathrm{pH}$ 9.5. The final lead dissolution for both cerussite and hydrocerussite are summarized in Table 2. Hydrocerussite demonstrated a lower solubility at lower temperature; however, cerussite exhibited a higher solubility which is not expected.

At $20^{\circ} \mathrm{C}$, cerussite was less soluble than hydrocerussite at all $\mathrm{pH}$ levels which was in agreement with other researchers [22] [24]. On the contrary, at $5^{\circ} \mathrm{C}$ cerussite showed higher solubility than hydrocerussite. These findings that showed cerussite and hydrocerussite had different dissolving behavior in different temperature may be of significance as it would imply that distribution systems with cerussite may experience higher than anticipated lead dissolution during cold time frames. To date, limited tests have been conducted at $5^{\circ} \mathrm{C}$ thus more research at $5^{\circ} \mathrm{C}$ is recommended.

\subsection{Alkalinity Experiments}

Carbonate alkalinity (DIC) as a water quality parameter can limit corrosion scale destabilization and lead dissolution [24]. The impact of alkalinity level was investigated on the lead solubility at $\mathrm{pH} 8.0$ at different temperatures, and the results are shown in Figure 2. Comparing the same solutions at different temperatures; lower temperature significantly decreased the lead dissolution (average $75 \mu \mathrm{g} / \mathrm{L}$ at $20^{\circ} \mathrm{C}$ vs. average $50 \mu \mathrm{g} / \mathrm{L}$ at $5^{\circ} \mathrm{C}$ ).

Final lead dissolution results at 45 days for cerussite and hydrocerussite at $\mathrm{pH} 8.0$ at $20^{\circ} \mathrm{C}$ and $5^{\circ} \mathrm{C}$ are shown in Table 3. It was observed that different alkalinity level impacted differently on the solubility of hydrocerussite and cerussite. At $20^{\circ} \mathrm{C}$, regardless of lead species, $\mathrm{NaHCO}_{3}$ which indicates moderate alkalinity resulted in less lead dissolution than $\mathrm{CaCO}_{3}$ which indicates low alkalinity $(95.17 \mu \mathrm{g} / \mathrm{L}$ for cerrusite and $96.01 \mu \mathrm{g} / \mathrm{L}$ for hydrocerussite). Further, at $20^{\circ} \mathrm{C}$ hydrocerussite dissolution is higher than cerussite, which is in agreement with the results obtained in Section 3.1 for $20^{\circ} \mathrm{C}$ experiments.

At $5^{\circ} \mathrm{C}$, similar to results from Section 3.1 has much more fluctuation in the data. In the low alkalinity condition, the solubility of hydrocerussite $(62.07 \mu \mathrm{g} / \mathrm{L})$ was more than cerussite $(52.03 \mu \mathrm{g} / \mathrm{L})$. However, in moderate

Table 2. Final dissolved lead after 45 days for cerussite and hydrocerussite with moderate alkalinity at various pH values.

\begin{tabular}{|c|c|c|c|}
\hline Lead Species & $\mathrm{pH}$ & Temperature & Final dissolved lead $(\mu \mathrm{g} / \mathrm{L})$ \\
\hline Cerussite & 7.0 & $20^{\circ} \mathrm{C}$ & $69.10 \pm 1.65$ \\
\hline Cerussite & 8.0 & $20^{\circ} \mathrm{C}$ & $62.35 \pm 1.65$ \\
\hline Cerussite & 9.5 & $20^{\circ} \mathrm{C}$ & $47.71 \pm 0.36$ \\
\hline Cerussite & 7.0 & $5^{\circ} \mathrm{C}$ & $132.89 \pm 7.50$ \\
\hline Cerussite & 8.0 & $5^{\circ} \mathrm{C}$ & $75.85 \pm 17.92$ \\
\hline Cerussite & 9.5 & $5^{\circ} \mathrm{C}$ & N/A \\
\hline Hydrocerussite & 7.0 & $20^{\circ} \mathrm{C}$ & $72.50 \pm 1.09$ \\
\hline Hydrocerussite & 8.0 & $20^{\circ} \mathrm{C}$ & $72.73 \pm 0.25$ \\
\hline Hydrocerussite & 9.5 & $20^{\circ} \mathrm{C}$ & $80.52 \pm 2.04$ \\
\hline Hydrocerussite & 7.0 & $5^{\circ} \mathrm{C}$ & $53.57 \pm 25.67$ \\
\hline Hydrocerussite & 8.0 & $5^{\circ} \mathrm{C}$ & $52.03 \pm 0.49$ \\
\hline Hydrocerussite & 9.5 & $5^{\circ} \mathrm{C}$ & $70.90 \pm 5.70$ \\
\hline
\end{tabular}


Table 3. Final dissolved lead after 45 days for cerussite and hydrocerussite at pH 8.0 with different alkalinity levels.

\begin{tabular}{cccc}
\hline Lead Species & Alkalinity Level & Temperature & Final Dissolved Lead $(\mu \mathrm{g} / \mathrm{L})$ \\
\hline Cerussite & Low & $20^{\circ} \mathrm{C}$ & $95.17 \pm 2.06$ \\
Cerussite & Moderate & $20^{\circ} \mathrm{C}$ & $62.35 \pm 1.65$ \\
Cerussite & Low & $5^{\circ} \mathrm{C}$ & $52.03 \pm 0.30$ \\
Cerussite & Moderate & $5^{\circ} \mathrm{C}$ & $75.87 \pm 17.92$ \\
Hydrocerussite & Low & $20^{\circ} \mathrm{C}$ & $96.01 \pm 2.16$ \\
Hydrocerussite & Moderate & $20^{\circ} \mathrm{C}$ & $72.73 \pm 0.25$ \\
Hydrocerussite & Low & $5^{\circ} \mathrm{C}$ & $62.07 \pm 18.86$ \\
Hydrocerussite & Moderate & $5^{\circ} \mathrm{C}$ & $53.20 \pm 0.49$ \\
\hline
\end{tabular}

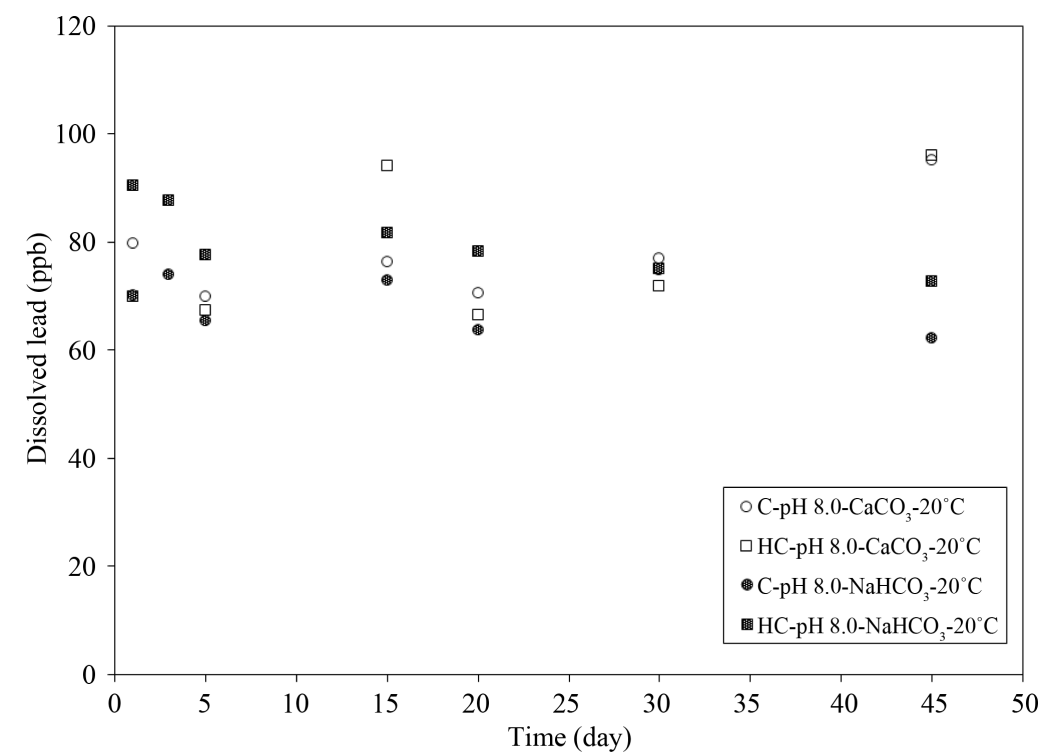

(a)

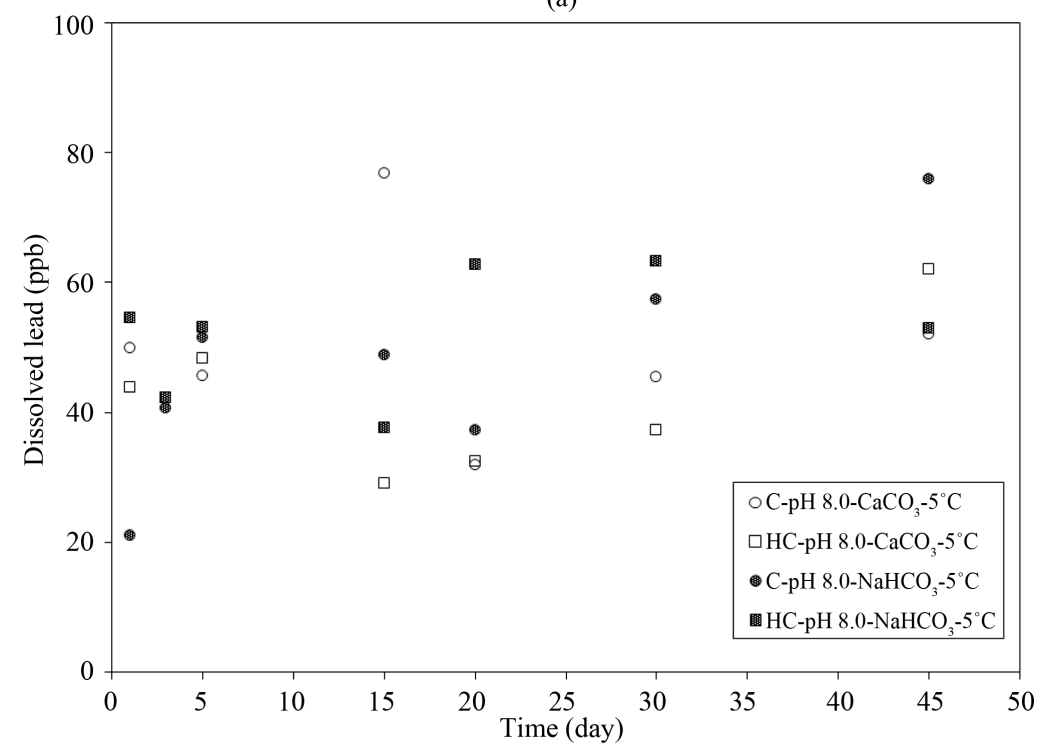

(b)

Figure 2. Effect of alkalinity on lead solubility for cerussite and hydrocerussite at (a) $20^{\circ} \mathrm{C}$ and (b) $5^{\circ} \mathrm{C} . \mathrm{NaHCO}_{3}$ indicates moderate alkalinity and $\mathrm{CaCO}_{3}$ indicates low alkalinity. 
alkalinity condition, cerussite $(75.87 \mu \mathrm{g} / \mathrm{L})$ showed more solubility than hydrocerussite $(53.20 \mu \mathrm{g} / \mathrm{L})$, which was in agreement with the results obtained in Section 3.1 for $5^{\circ} \mathrm{C}$ experiments. These results clearly demonstrated lead dissolution impacted by level of alkalinity.

\subsection{Role of Free Chlorine}

Changes in water treatment processes will result in different water chemistry and ultimately influence the solubility of the existing lead species in corrosion scale. Using chlorine as disinfectant will result in the formation of disinfection by products (DBPs). To avoid DBPs, some treatment plants changed the disinfectant from free chlorine to monochloramine which resulted to higher lead dissolution [24] [29]. The higher solubility of lead in such drinking water is due to the lower oxidation reduction potential (ORP) of monochloramine which favors the formation of hydrocerussite [22] [30].

Hydrocerussite and cerussite are the most soluble lead components in the corrosion scale. For that reason to decrease lead dissolution in drinking water, these two species have to be transformed to low soluble $\mathrm{PbO}_{2}$. Facilitating the formation of $\mathrm{PbO}_{2}$ requires free chlorine which can raise the redox potential while chloramines cannot provide such a high oxidative condition [22] [24] [27].

The transformation process of lead carbonates to lead oxides is as follows: Hydrocerussite $\rightarrow$ Cerussite $\rightarrow$ Plattnerite $\rightarrow$ Scrutinyite [22].

As mentioned in Section 3.1, the overall reactions occur in corrosion scale hypothesized by Kim and Herrera [22]:

$$
\begin{gathered}
\mathrm{Pb}_{3}\left(\mathrm{CO}_{3}\right)_{2}(\mathrm{OH})_{2}+\mathrm{H}_{2} \mathrm{CO}_{2} \rightleftharpoons 3 \mathrm{PbCO}_{3}+2 \mathrm{H}_{2} \mathrm{O} \\
3 \mathrm{PbCO}_{3}+\mathrm{HOCl}+3 \mathrm{H}_{2} \mathrm{O} \rightleftharpoons \mathrm{Pb}_{3} \mathrm{O}_{4}+\mathrm{HCl}+3 \mathrm{H}_{2} \mathrm{CO}_{3} \\
\mathrm{~Pb}_{3} \mathrm{O}_{4}+2 \mathrm{HOCl} \rightleftharpoons 3 \mathrm{PbO}_{2}+2 \mathrm{HCl}
\end{gathered}
$$

In this study the initial concentration of free chlorine was $1 \mathrm{mg} / \mathrm{L}$. Chlorine was consumed to oxidize lead (II) to lead (IV) and reduce the lead solubility. At $20^{\circ} \mathrm{C}$ experiments (Figure 1(a) and Figure 2(a)), regardless of DIC, chlorine concentration reduced to $0.5 \mathrm{mg} / \mathrm{L}$ or less by day 5 . From day 0 to day 5 , large changes in lead level was observed, however, once the chlorine level decreased to less than $0.5 \mathrm{mg} / \mathrm{L}$ the change in lead concentration decreased significantly. This result is expected because decay of chlorine at $20^{\circ} \mathrm{C}$ occurs relatively fast.

At $5^{\circ} \mathrm{C}$ (Figure 1(b)), at moderate alkalinity, free chlorine was more than $0.5 \mathrm{mg} / \mathrm{L}$ till day 30 for hydrocerussite and day 20 for cerussite which is in general agreement with the lead dissolution results that show higher lead concentration for cerussite at day 45 rather than hydrocerussite at day 45 . Figure 3 shows free chlorine concentration during the experiment for $\mathrm{pH} 8.0$ and moderate alkalinity.

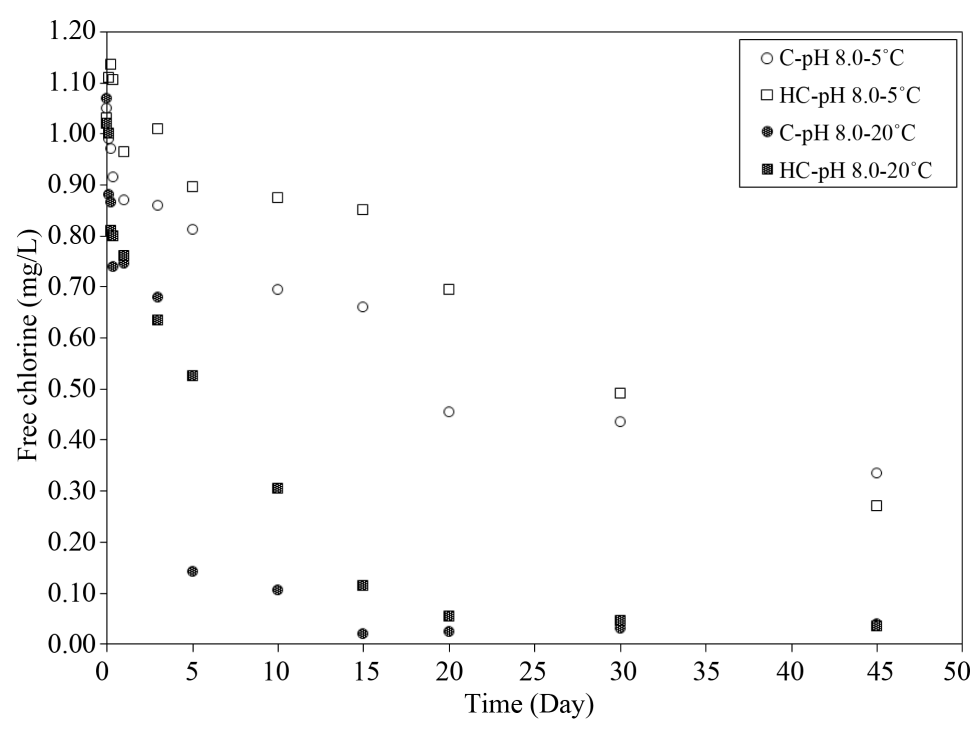

Figure 3. Free chlorine concentration during 45 days of experiment at $5^{\circ} \mathrm{C}$ and $20^{\circ} \mathrm{C}$, with $\mathrm{pH} 8.0$ and moderate alkalinity. 
At $5^{\circ} \mathrm{C}$, at low alkalinity, free chlorine was above $0.5 \mathrm{mg} / \mathrm{L}$ up to day 15 for both cerussite and hydrocerussite. Interestingly after day 15 , hydrocerussite solubility increased significantly but cerussite solubility did not. This would indicate that there were mechanistic differences in dissolution of lead when exposed to different levels of alkalinity.

\section{Conclusions}

Cerussite and hydrocerussite as the major lead species in distribution systems were used in this project to investigate lead dissolution at various temperature and $\mathrm{pH}$. The impact of free chlorine and alkalinity on lead solubility was studied as well. Bench-scale experiments were conducted and the following are the conclusions:

- Cerussite and hydrocerussite solubility somewhat surprisingly were not impacted significantly by $\mathrm{pH}$ value ranging from 7.0 to 9.5. However, there were clear impact associated with temperature and alkalinity level on cerussite and hydrocerussite dissolution and can be considered as good predictors for dissolution.

- As expected, lower dissolution for hydrocerussite was observed at $5^{\circ} \mathrm{C}$ rather than $20^{\circ} \mathrm{C}$.

- Considering the effect of alkalinity and temperature, at both $20^{\circ} \mathrm{C}$ and $5^{\circ} \mathrm{C}$, low alkalinity resulted in higher dissolution of cerussite and hydrocerussite.

- Hydrocerussite was always found to be more soluble at low alkalinity regardless of temperature.

- Mix results were found with moderate alkalinity. At $20^{\circ} \mathrm{C}$, hydrocerussite was more soluble than cerussite, whereas at $5^{\circ} \mathrm{C}$ cerussite was more soluble than hydrocerussite.

\section{Acknowledgements}

This work was part of a collaborative project between Carleton University and Western University that was funded by Canadian Water Network. We are grateful for the advice of Dr. Nimal De Silva (Ottawa University, Canada) on ICP analysis and for the assistance of Dr. Marie Tudoret, Miaoyi Yan from Carleton University, Canada and Dr. Claire Robinson, Caitlin Kushnir and Daoping Guo from Western University, Canada.

\section{References}

[1] Kim, E.J., Herrera, J.E., Huggins, D., Braam, J. and Koshowski, S. (2011) Effect of pH on the Concentrations of Lead and Trace Contaminants in Drinking Water: A Combined Batch, Pipe Loop and Sentinel Home Study. Water Research, 45, 2763-2774. http://dx.doi.org/10.1016/j.watres.2011.02.023

[2] Mielke, H.W., Gonzales, C.R. and Mielke Jr., P.W. (2011) The Continuing Impact of Lead Dust on Children’s Blood Lead: Comparison of Public and Private Properties in New Orleans. Environmental Research, 111, 1164-1172. http://dx.doi.org/10.1016/j.envres.2011.06.010

[3] Karatas, M. (2012) Removal of Pb(II) from Water by Natural Zeolitic Tuff: Kinetics and Thermodynamics. Journal of Hazardous Materials, 199-200, 383-389. http://dx.doi.org/10.1016/j.jhazmat.2011.11.035

[4] Pizzol, M., Thomsen, M. and Andersen, M.S. (2010) Long-Term Human Exposure to Lead from Different Media and Intake Pathways. Science of the Total Environment, 408, 5478-5488. http://dx.doi.org/10.1016/j.scitotenv.2010.07.077

[5] Ahamed, M. and Siddiqui, M.K.J. (2007) Environmental Lead Toxicity and Nutritional Factors. Clinical Nutrition, 26, 400-408. http://dx.doi.org/10.1016/j.clnu.2007.03.010

[6] Hu, J., Ma, Y.W., Zhang, L., Gan, F.X. and Ho, Y.-S. (2010) A Historical Review and Bibliometric Analysis of Research on Lead in Drinking Water Field from 1991 to 2007. Science of the Total Environment, 408, 1738-1744. http://dx.doi.org/10.1016/j.scitotenv.2009.12.038

[7] Baranowska-Bosiacka, I., Gutowska, I., Marchlewicz, M., Marchetti, C., Kurzawski, M., Dziedziejko, V., Kolasa, A., Olszewsa, M., Rybicka, M., Safranow, K., Nowacki, P., Wiszniewska, B. and Chlubek, D. (2012) Disrupted Pro- and Antioxidative Balance as a Mechanism of Neurotoxicity Induced by Perinatal Exposure to Lead. Brain Research, 1435, 56-71. http://dx.doi.org/10.1016/j.brainres.2011.11.062

[8] Baranowska-Bosiacka, I., Strużyńska, L., Gutowska, I., Machalińska, A., Kolasa, A., Kłos, P., Czapski, G.A., Kurzawski, M., Prokopowicz, A., Marchlewicz, M., Safranow, K., Machaliński, B., Wiszniewska, B. and Chlubek, D. (2013) Perinatal Exposure to Lead Induces Morphological, Ultrastructural and Molecular Alterations in the Hippocampus. Toxicology, 303, 187-200. http://dx.doi.org/10.1016/j.tox.2012.10.027

[9] Bierkens, J., Buekers, J., Van Holderbeke, M. and Torfs, R. (2012) Health Impact Assessment and Monetary Valuation of IQ Loss in Pre-School Children Due to Lead Exposure through Locally Produced Food. Science of the Total Environment, 414, 90-97. http://dx.doi.org/10.1016/j.scitotenv.2011.10.048

[10] Finkelstein, Y., Markowitz, M.E. and Rosen, J.F. (1998) Low-Level Lead-Induced Neurotoxicity in Children: An Up- 
date on Central Nervous System Effects. Brain Research Reviews, 27, 168-176. http://dx.doi.org/10.1016/S0165-0173(98)00011-3

[11] Sanders, T., Liu, Y.M., Buchner, V. and Tchounwou, P.B. (2009) Neurotoxic Effects and Biomarkers of Lead Exposure: A Review. Reviews on Environmental Health, 24, 15-46. http://dx.doi.org/10.1515/REVEH.2009.24.1.15

[12] Ortega, F., Counter, S.A., Buchanan, L.H., Coronel Parra, A.M., Collaguaso, M.A., Jacobs, A.B., Rifai, N. and Hoover, P.N. (2013) Declining Blood Lead and Zinc Protoporphyrin Levels in Ecuadorian Andean Children. Clinical Biochemistry, 46, 1233-1238. http://dx.doi.org/10.1016/j.clinbiochem.2013.05.002

[13] Recio-Vega, R., Valdez-Abrego, C., Adame-Lopez, B. and Gurrola-Mendez, A. (2012) Surveillance of Elevated Blood Lead Levels in Children in Torreon, Coahuila, Mexico, 1998-2010. International Journal of Hygiene and Environmental Health, 215, 507-513. http://dx.doi.org/10.1016/j.ijheh.2011.10.009

[14] Jones, D.J. (2012) Primary Prevention and Health Outcomes: Treatment of Residential Lead-Based Paint Hazards and the Prevalence of Childhood Lead Poisoning. Journal of Urban Economics, 71, 151-164. http://dx.doi.org/10.1016/j.jue.2011.06.002

[15] Lyle, D.M., Phillips, A.R., Balding, W.A., Burke, H., Stokes, D., Corbett, S. and Hall, J. (2006) Dealing with Lead in Broken Hill-Trends in Blood Lead Levels in Young Children 1991-2003. Science of the Total Environment, 359, 111-119. http://dx.doi.org/10.1016/j.scitotenv.2005.04.022

[16] Hwang, Y.-H., Ko, Y., Chiang, C.-D., Hsu, S.-P., Lee, Y.-H., Yu, C.-H., Chiou, C.-H., Wang, J.-D. and Chuang, H.-Y. (2004) Transition of Cord Blood Lead Level, 1985-2002, in the Taipei Area and Its Determinants after the Cease of Leaded Gasoline Use. Environmental Research, 96, 274-282. http://dx.doi.org/10.1016/j.envres.2004.02.002

[17] Health Canada (2012) Guidelines for Canadian Drinking Water Quality—Summary Table. Water, Air and Climate Change Bureau, Healthy Environments and Consumer Safety Branch, Health Canada, Ottawa.

[18] USEPA (2009) National Primary Drinking Water Regulations. United States Environmental Protection Agency EPA 816-F-09-004, May 2009.

[19] National Health and Medical Research Council (NHMRC) and National Resource Management Ministerial Council (NRMMC) (2011) National Water Quality Management Strategy Australian Drinking Water Guidelines 6.

[20] World Health Organization (2011) Guidelines for Drinking-Water Quality. 4th Edition, WHO, Geneva.

[21] SCHER, Scientific Committee on Health and Environmental Risks (2011) Lead Standard in Drinking Water.

[22] Kim, E.J. and Herrera, J.E. (2010) Characteristics of Lead Corrosion Scales Formed during Drinking Water Distribution and Their Potential Influence on the Release of Lead and Other Contaminants. Environmental Science Technology, 44, 6054-6061. http://dx.doi.org/10.1021/es101328u

[23] Lasheen, M.R., Sharaby, C.M., El-Kholy, N.G., Elsherif, I.Y. and El-Wakeel, S.T. (2008) Factors Influencing Lead and Iron Release from Some Egyptian Drinking Water Pipes. Journal of Hazardous Materials, 160, 675-680. http://dx.doi.org/10.1016/j.jhazmat.2008.03.040

[24] Xie, Y.L., Wang, Y., Singhal, V. and Giammar, D.E. (2010) Effects of pH and Carbonate Concentration on Dissolution Rates of the Lead Corrosion Product $\mathrm{PbO}_{2}$. Environmental Science Technology, 44, 1093-1099. http://dx.doi.org/10.1021/es9026198

[25] Wang, Y., Wu, J.W., Wang, Z.M., Terenyi, A. and Giammar, D.E. (2013) Kinetics of Lead (IV) Oxide $\left(\mathrm{PbO}_{2}\right) \mathrm{Reduc}^{-}$ tive Dissolution: Role of Lead(II) Adsorption and Surface Speciation. Journal of Colloid and Interface Science, 389, 236-243. http://dx.doi.org/10.1016/j.jcis.2012.09.022

[26] Noel, J.D., Wang, Y. and Giammar, D.E. (2014) Effect of Water Chemistry on the Dissolution of the Lead Corrosion Product Hydrocerussite. Water Research, 54, 237-246. http://dx.doi.org/10.1016/j.watres.2014.02.004

[27] Xie, Y.L. and Giammar, D.E. (2011) Effects of Flow and Water Chemistry on Lead Release Rates from Pipe Scales. Water Research, 45, 6525-6534. http://dx.doi.org/10.1016/j.watres.2011.09.050

[28] Liu, H., Korshin, G.V., Ferguson, J.F. and Jiang, W. (2006) Key Parameters and Kinetics of Oxidation of Lead (II) Solid Phases by Chlorine in Drinking Water. Water Practice \& Technology, 1, 7 p.

[29] Switzer, J.A., Rajasekharan, V.V., Boonsalee, S., Kulp, E.A. and Bohannan, E.W. (2006) Evidence That Monochloramine Disinfectant Could Lead to Elevated Pb Levels in Drinking Water. Environmental Science Technology, 40, 33843387. http://dx.doi.org/10.1021/es052411r

[30] Edwards, M. (2014) Fetal Death and Reduced Birth Rates Associated with Exposure to Lead-Contaminated Drinking Water. Environmental Science Technology, 48, 739-746. http://dx.doi.org/10.1021/es4034952 